\title{
The effects of cadmium and copper on embryonic and larval development of ide Leuciscus idus $\mathbf{L}$.
}

\author{
Malgorzata Witeska • Piotr Sarnowski • \\ Katarzyna Lugowska • Ewelina Kowal
}

Received: 15 April 2013/ Accepted: 5 July 2013/Published online: 25 July 2013

(C) The Author(s) 2013. This article is published with open access at Springerlink.com

\begin{abstract}
The effects of $\mathrm{Cd}$ and $\mathrm{Cu}$ on embryos and larvae of the ide Leuciscus idus were evaluated. The ide is an European cyprinid fish, natural populations of which tend to decrease. The ide is also used as a bioindicator organism to evaluate water quality. However, sensitivity of ide early developmental stages to heavy metal intoxication is not known. Fish were exposed to $\mathrm{Cd}$ or $\mathrm{Cu}(100 \mu \mathrm{g} / \mathrm{L})$ during embryonic, larval or both developmental periods. Survival of the embryos, time of hatching, size and quality of newly hatched larvae were evaluated at the end of embryonic period. Correctly developed larvae from the control and $\mathrm{Cd}$ or $\mathrm{Cu}$-exposed groups were transferred to clean water, $\mathrm{Cd}$ or $\mathrm{Cu}$ solutions $(100 \mu \mathrm{g} / \mathrm{L})$ immediately after hatching. Larval development was observed, and the larvae were photographed. Time of yolk sac resorption, onset of active feeding and swim bladder inflation were evaluated, and the measurements were done on body and swim bladder size. The results showed that exposure of embryos to $\mathrm{Cd}$ and $\mathrm{Cu}$ significantly reduced embryonic survival and increased frequency of body malformations and death in newly hatched larvae and delayed hatching.
\end{abstract}

M. Witeska ( $)$ · P. Sarnowski · K. Ługowska ·

E. Kowal

Department of Animal Physiology, University of Natural

Sciences and Humanities, Prusa 12,

08-110 Siedlce, Poland

e-mail: wites@uph.edu.pl
Exposure to $\mathrm{Cd}$ and $\mathrm{Cu}$ during larval period reduced larval survival, growth and delayed development (yolk utilization, beginning of active feeding and swim bladder inflation). Cadmium was more toxic to the ide embryos and larvae than copper. Exposures to metals during embryonic period alone caused adverse impact on larval performance even when larval development took place in clean water. However, exposure of embryos to $\mathrm{Cu}$ reduced toxic impact of metal on larvae in continuous $\mathrm{Cu}$ exposure compared to the nonpreexposed fish, but no such an effect occurred in case of $\mathrm{Cd}$ exposure. The results show that even a shortterm exposure to $\mathrm{Cd}$ or $\mathrm{Cu}$ during early development of ide may adversely affect recruitment of this species. Among the measured endpoints, quality of newly hatched larvae (frequency of body malformations and larvae dead immediately after hatching) and swim bladder size were the most sensitive to intoxication with both metals. Embryos were more sensitive to $\mathrm{Cu}$ intoxication than larvae, while in case of $\mathrm{Cd}$, sensitivity of both stages was similar.

Keywords Fish - Embryos - Larvae . Heavy metals · Toxicity

\section{Introduction}

The ide (Leuciscus idus L.) is a mostly riverine cyprinid fish species inhabiting large and medium size 
rivers in Europe and Asia. They are planktivorous and benthivorous, of average body size of $40-50 \mathrm{~cm}$, prefer deep, clean and cool water and reach sexual maturation at the age of 3-4 years. Spawning takes place from April to June at sandy or gravel spawning substrate. According to Hamackova et al. (2007), in some European countries (e.g., Czech Republic), the ide belongs to less frequent and vulnerable species; thus, it is bred in captivity and reared under controlled conditions. Also, in Poland, natural populations of many rheophilic fish including the ide are dwindling due to environment deterioration, and the fish are artificially reproduced and prereared under hatchery conditions (Wolnicki and Górny 1995) and cultured in carp farms (Cieśla and Wojda 2004; Krejszeff et al. 2009). L. idus is also used to assess the quality of surface water (Allner et al. 1999; Fenske et al. 2006) and for toxicity tests (Braunbeck and Segner 1992; Lenyen et al. 1998). However, all these studies were performed on juvenile or adult fish, while little is known about sensitivity of the early life stages of ide to environmental contaminants.

Fish embryos and larvae are more sensitive to environmental impacts, including toxic substances compared to the juveniles and adults (Dave and Xiu 1991). Various embryonic morphological, physiological and behavioral endpoints are used to assess toxicity of chemicals (Weis et al. 2003; Fraysse et al. 2006). Fish larvae are also a useful animal model for toxicity evaluation since they are small but developed enough to have almost all functional organs (Hernandez and Allende 2008). Sensitivity of various early developmental stages to intoxication is different, and so is sensitivity of various endpoints (Nguyen and Janssen 2002; Jezierska et al. 2009a, b).

Cadmium is a xenobiotic, while copper is an important essential metal. However, both are widespread and highly toxic environmental pollutants. Copper sulfate is also used in fish culture to control saprolegniosis on eggs (Straus et al. 2012) and as an antibacterial agent for treatment of larvae (Chen et al. 2006). Various studies showed that sublethal concentrations of these metals are toxic to fish embryos and larvae, and various physiological disturbances were observed.

In unpolluted freshwaters, the levels of $\mathrm{Cd}$ and $\mathrm{Cu}$ range from 0 to 13 and 2 to $4 \mu \mathrm{g} / \mathrm{L}$, respectively. Contaminated waters often contain much more: $40-120 \mu \mathrm{g} / \mathrm{L}$ of $\mathrm{Cd}$ and $1-137 \mu \mathrm{g} / \mathrm{L}$ of $\mathrm{Cu}$ (Dojlido
1995). Cadmium and copper under acidic conditions are leached from the sediments, so, the concentrations of free $\mathrm{Cu}^{2+}$ and $\mathrm{Cd}^{2+}$ ions may temporarily increase. Spring snowmelt often acidifies water; thus, the risk of contamination coincides with spawning and development of early stages of fish. According to Zyśk (2013), sediments of Vistula River contain $2 \mathrm{mg} / \mathrm{kg}$ of Cd and $12 \mathrm{mg} / \mathrm{kg}$ of $\mathrm{Cu}$, while Adamiec and Helios-Rybicka (2002) reported 3-21 mg/kg of Cd and 31.3-298 mg/ $\mathrm{kg}$ of $\mathrm{Cu}$ in sediments of Odra River.

According to Paquin et al. (2002), acute toxic action of metals involves ionoregulatory disturbances by affecting the activity of $\mathrm{Na}^{+} / \mathrm{K}^{+}$ATPase and displacement of calcium from paracellular junctions which results in increased permeability of epithelia and in consequence in sodium loss from the organism.

There are many data showing toxicity of cadmium to early life stages of various fish species. Short-time pulse-exposure of Melanotaenia fluviatilis embryos and larvae to $3,300 \mu \mathrm{g} / \mathrm{L}$ of Cd resulted in embryonic deformities reduced percentage of hatched larvae and larval spinal deformities (Williams and Holdway 2000). According to Ismail and Yusof (2011), exposure of fertilized eggs of Oryzias javanicus to low levels of cadmium $(10-50 \mu / \mathrm{L})$ caused developmental disorders, while concentration of $100 \mu / \mathrm{L}$ completely inhibited development and resulted in death of all embryos. Lizardo-Daudt and Kennedy (2008) reported disturbances of hatching, reduced growth and endocrine disruption in Oncorhynchus mykiss larvae subjected from fertilization to low concentrations of cadmium $(0.05-2.5 \mu \mathrm{g} / \mathrm{L})$. Developmental defects and mortality were observed in embryos and pro-larvae of Silurus soldatovi exposed to various concentrations of cadmium (Zhang et al. 2012). Cadmium was also observed to induce oxidative stress in Paralichthys olivaceus larvae (Cao et al. 2010) and directly affected membrane calcium transport in Danio rerio larvae which resulted in reduced $\mathrm{Ca}^{2+}$ uptake (Liu et al. 2012).

Toxicity of copper to early developmental stages of fish is also well documented. Chen et al. (2012) reported that even short-term pulsed exposure to low levels of copper reduced growth rate of Oreochromis mossambicus larvae. Nguyen and Janssen (2002) reported that copper reduced growth and caused morphological anomalies in Clarias gariepinus larvae. According to Johnson et al. (2007), copper exposure $(11-1,000 \mu \mathrm{g} / \mathrm{L})$ of $D$. rerio embryos 
resulted in mortality, hatching inhibition, impairment of larval development and lateral line dysfunction. The latter effect of copper was also reported by (Hernandez et al. 2006 and Linbo et al. 2006, 2009).

Barjhoux et al. (2012) reported that both cadmium and copper induced morphological anomalies and genotoxic effect in Oryzias latipes embryos and larvae. Sikorska and Wolnicki (2010) exposed Tinca tinca larvae to $100-300 \mu \mathrm{g} / \mathrm{L}$ of cadmium or copper and observed reduced growth and survival and retarded swim bladder inflation. The highest concentrations of both metals delayed the onset of exogenous feeding. According to Alsop and Wood (2011), there is a common pathway for uptake of several heavy metals including cadmium and copper and a common mechanism of toxicity, probably total ion loss by diffusion.

Some data suggest the possibility of acclimation of early stages of fish to cadmium and copper by pretreatment due to stimulation of metallothionein synthesis (Wu and Hwang 2003).

Our previous studies showed that cadmium and copper at the concentrations of $100 \mu \mathrm{g} / \mathrm{L}$ adversely affected embryonic and larval survival and development of various species of cyprinid fish: Cyprinus carpio and Barbus barbus (Jezierska and Slominska 1997; Slominska and Jezierska 2000; Jezierska et al. 2009a, b; Witeska et al. 2010; Ługowska and Kubik 2011).

The aim of present study was to evaluate the effects of cadmium and copper on embryonic and larval development of the ide $L$. idus and to compare sensitivity of various developmental stages and endpoints to toxic action of these metals.

\section{Materials and methods}

The eggs and sperms of the ide were obtained from the hatchery of Samoklęski Fish Farm in Kamionka, Poland. Chilled gametes were transported to the laboratory in the cold box at $5{ }^{\circ} \mathrm{C}$ for about $2 \mathrm{~h}$. Then the eggs and sperms were gradually warmed up to the ambient temperature and in vitro fertilization took place. Fertilized eggs were placed in glass Petri dishes and these-in $2 \mathrm{~L}$ aquaria. Water was constantly gently aerated, and constant temperature $16{ }^{\circ} \mathrm{C}$ was maintained using thermostat, $\mathrm{pH}$ was 7.8-8.0, total hardness $178 \mathrm{mg} / \mathrm{dm}^{3}$ as $\mathrm{CaCO}_{3}$, DO saturation $\geq 80 \%, \mathrm{NH}_{4}{ }^{+} 50 \mu \mathrm{g} / \mathrm{L}, \mathrm{NO}_{2}{ }^{-} 5 \mu \mathrm{g} / \mathrm{L}$. Clean nonchlorinated tap water used in the experiment contained $<1 \mu \mathrm{g} / \mathrm{L}$ of $\mathrm{Cd}$ and $<40 \mu \mathrm{g} / \mathrm{L}$ of $\mathrm{Cu}$ and $4.0 \mathrm{mg} / \mathrm{L}$ of $\mathrm{Na}$ and $55.7 \mathrm{mg} / \mathrm{L}$ of $\mathrm{Ca}$. Three experimental groups were created: control- the embryos were incubated in clean water, $\mathrm{Cd}$-incubation took place in water containing $100 \mu \mathrm{g} / \mathrm{dm}^{3}$ of cadmium (as $\mathrm{CdCl}_{2} \times 21$ / $2 \mathrm{H}_{2} \mathrm{O}$ ) and $\mathrm{Cu}-$ in water containing $100 \mu \mathrm{g} / \mathrm{dm}^{3}$ of copper (as $\mathrm{CuSO}_{4} \times 5 \mathrm{H}_{2} \mathrm{O}$ ). Each group consisted of 4 dishes (replicates), on average 161 (146-183) eggs in each. Water was changed every day by gentle siphoning out and replacement with fresh clean water (control) or fresh metal solutions $(\mathrm{Cd}$ and $\mathrm{Cu}$ ). During embryonic period development, observations were made twice a day and dead embryos were counted and removed (opaque eggs). Time of hatching and final survival of newly hatched larvae was calculated. The quality of newly hatched larvae was also evaluated, and percentage was calculated of correctly developed and viable, deformed (showing various morphological anomalies such as vertebral curvatures and yolk sac malformations), and dead-those that died immediately after hatching.

Correctly developed and viable newly hatched larvae were transferred to $14 \mathrm{~L}$ aerated aquaria and divided into 7 experimental groups, 50 larvae in each (Table 1). Every day, the larvae were gently harvested with the plastic sieve, counted and transferred to clean aquarium with fresh water or metal solution, respectively. At the same time, dead larvae were also counted and removed. During larval development, constant water temperature $18{ }^{\circ} \mathrm{C}$ was maintained, $\mathrm{pH}$ was 7.8-8.0, water hardness $178 \mathrm{mg} / \mathrm{dm}^{3}$ as $\mathrm{CaCO}_{3}$ and DO saturation $\geq 80 \%$ ). Constant gentle aeration was applied. Beginning from the 3 day post-hatching (dph), the larvae were fed 3 times a day Artemia nauplii ad libitum. Experimental rearing lasted 21 days.

Immediately after hatching, 30 larvae from each group (Control, $\mathrm{Cd}$ and $\mathrm{Cu}$ ) were photographed using stereoscopic microscope connected with the camera and computer with MultiScan image analysis system (Computer Scanning Systems, Poland). During larval exposure, 20 larvae from each group (Control, $\mathrm{Cd}-\mathrm{Cd}$, $\mathrm{Cu}-\mathrm{Cu}, \mathrm{Cd}-0, \mathrm{Cu}-0,0-\mathrm{Cd}$ and $0-\mathrm{Cu}$ ) were photographed daily until the end of the experiment (21 dph). The larvae were individually placed in a watch glass with water or metal solution under microscope; magnification was adjusted to the increasing size of 
Table 1 Experimental groups and their development conditions

\begin{tabular}{llll}
\hline Group & Embryonic development & Larval development & $\begin{array}{l}\text { Number } \\
\text { of fish }\end{array}$ \\
\hline Control & Clean water & Clean water & 50 \\
$\mathrm{Cd}-\mathrm{Cd}$ & $\mathrm{Cd} 100 \mu \mathrm{g} / \mathrm{L}$ & $\mathrm{Cd} 100 \mu \mathrm{g} / \mathrm{L}$ & 50 \\
$\mathrm{Cu}-\mathrm{Cu}$ & $\mathrm{Cu} 100 \mu \mathrm{g} / \mathrm{L}$ & $\mathrm{Cu} 100 \mu \mathrm{g} / \mathrm{L}$ & 50 \\
$\mathrm{Cd}-0$ & $\mathrm{Cd} 100 \mu \mathrm{g} / \mathrm{L}$ & Clean water & 50 \\
$\mathrm{Cu}-0$ & $\mathrm{Cu} 100 \mu \mathrm{g} / \mathrm{L}$ & Clean water & 50 \\
$0-\mathrm{Cd}$ & Clean water & $\mathrm{Cd} 100 \mu \mathrm{g} / \mathrm{L}$ & 50 \\
$0-\mathrm{Cu}$ & Clean water & $\mathrm{Cu} 100 \mu \mathrm{g} / \mathrm{L}$ & 50 \\
\hline
\end{tabular}

larvae, and the scaled photographs were taken; then the larvae were returned back to the aquaria. Entire procedure for each larva took about $1 \mathrm{~min}$. All measurements were done in the photographs: body length, body perimeter area (excluding yolk sac), yolk sac perimeter area and swim bladder perimeter area (separately for posterior and anterior chamber). For evaluation of the effects of $\mathrm{Cd}$ and $\mathrm{Cu}$ on the shape of larvae, the ratio of body perimeter area to length was calculated for newly hatched and 21-day-old-larvae. For the newly hatched larvae, also, the ratio of yolk sac perimeter area to body perimeter area was calculated to evaluate relative size of nutrient abundance. Perimeter area of entire swim bladder was made by addition of the results to both chambers. Time of complete yolk sac resorption, first feeding (based on the presence of Artemia in the digestive tract) and the beginning of swim bladder inflation was also registered (when at least $50 \%$ of larvae showed the feature). For comparison between the sensitivity of various embryonic and larval endpoints to metal toxicity and of the effects of various exposures, percent change of mean values of the studied parameters in relation to the control was calculated.

The obtained results were subjected to statistical analysis using Statistica 9.1 (Stat Soft). Significance of differences among groups was tested using $t$ test at $p \leq 0.05$. For clarity of the results, only initial and final values were shown.

\section{Results}

Embryonic exposure to $\mathrm{Cd}$ and $\mathrm{Cu}$ significantly reduced survival at each developmental stage, $\mathrm{Cd}$ more than $\mathrm{Cu}$ (Fig. 1). Both metals caused a delay in the beginning and the end of hatching; in the control, hatching started $114 \mathrm{~h}$ post-fertilization (hpf) and ended 135 hpf, while in Cd-exposed group, 125 and 141, and in $\mathrm{Cu}$-exposed group, 128 and $150 \mathrm{hpf}$. Percentage of deformed and dead larvae significantly increased after $\mathrm{Cd}$ and $\mathrm{Cu}$ exposure of embryos (Fig. 2), and the effect of cadmium was significantly more pronounced compared to copper. The size of newly hatched larvae also significantly differed (Fig. 3): the shortest larvae hatched in the control, while the longest in $\mathrm{Cu}$-contaminated water, but body perimeter area did not significantly differ among the groups. The ratio of body perimeter area to body length was significantly lower in $\mathrm{Cu}$-exposed group $(0.81 \pm 0.06)$ compared to the control $(0.85 \pm 0.08)$ and $\mathrm{Cd}$ group $(0.87 \pm 0.10)$. Newly hatched larvae from $\mathrm{Cu}$ group showed significantly smaller yolk sac than fish from the control and Cd group (Fig. 4). The ratio of the yolk sac perimeter area to body perimeter area was $0.23 \pm 0.03$ in the control, $0.23 \pm 0.04$ in $\mathrm{Cd}$ and only $0.02 \pm 0.04$ in $\mathrm{Cu}$ group (significantly less than in control and $\mathrm{Cd}$ ).

The lowest larval mortality at the end of the experiment (on $21 \mathrm{dph}$ ) occurred in the control group (5\%), while the highest is in the $\mathrm{Cd}-\mathrm{Cd}$ group $(50 \%)$. Mortality in $\mathrm{Cd}-0$ and $0-\mathrm{Cd}$ was 25 and $33 \%$, respectively, while in $\mathrm{Cu}$-intoxicated groups: $\mathrm{Cu}-\mathrm{Cu}$, $\mathrm{Cu}-0$, and $0-\mathrm{Cu}: 18,12$, and $27 \%$, respectively.

Body size of larvae at the end of the experiment $(21 \mathrm{dph})$ significantly differed among experimental groups, body length less than perimeter area (Figs. 5, $6)$. The longest larvae were in the control and similar (slightly but insignificantly shorter) in $\mathrm{Cu}-0$ group, while the fish from $\mathrm{Cd}-\mathrm{Od}$ were the shortest. Similarly, as the length, also body perimeter area at the end of the experiment was the highest in the control and very similar in $\mathrm{Cu}-0$ group. Fish exposed to cadmium over entire embryonic and larval period $(\mathrm{Cd}-\mathrm{Cd})$ were the smallest (with body perimeter area about twice smaller compared to the control), while 
Fig. 1 The effects of exposure to $100 \mu \mathrm{g} / \mathrm{L}$ of cadmium or copper on survival of ide embryos at various developmental stages (different letter superscripts indicate significant differences among experimental groups at each developmental stage, $t$ test, $p \leq 0.05, n=4$ )

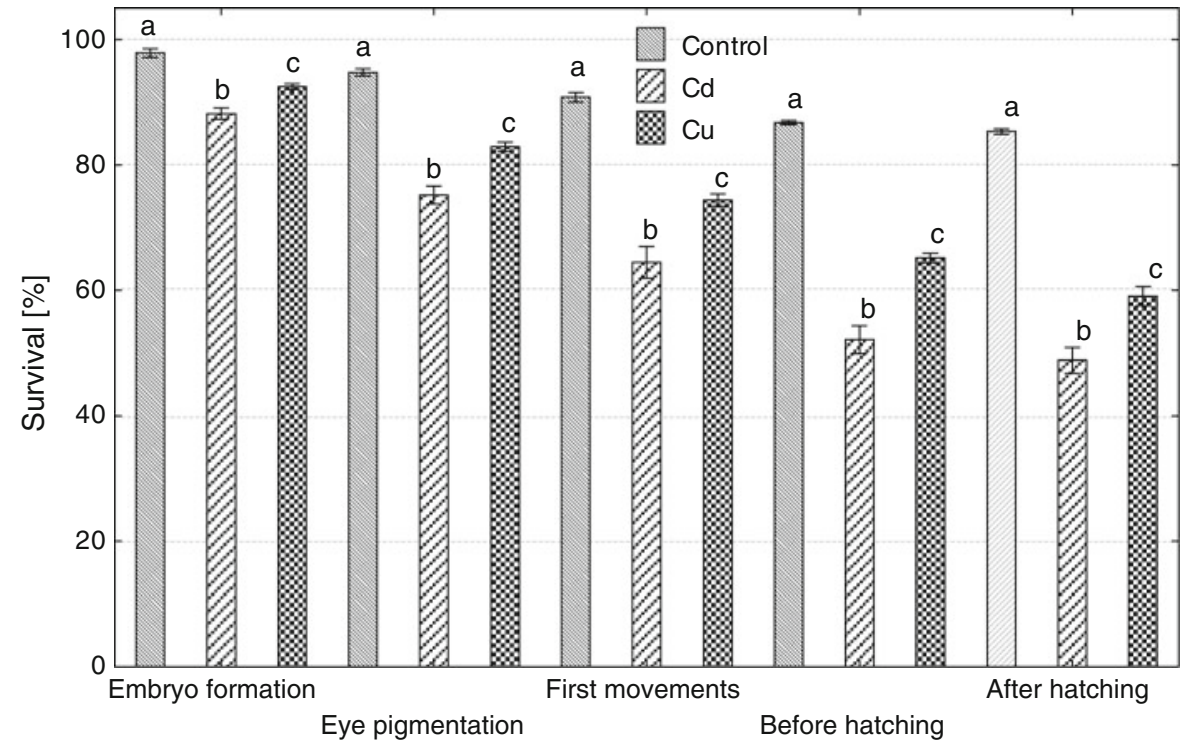

Developmental stage

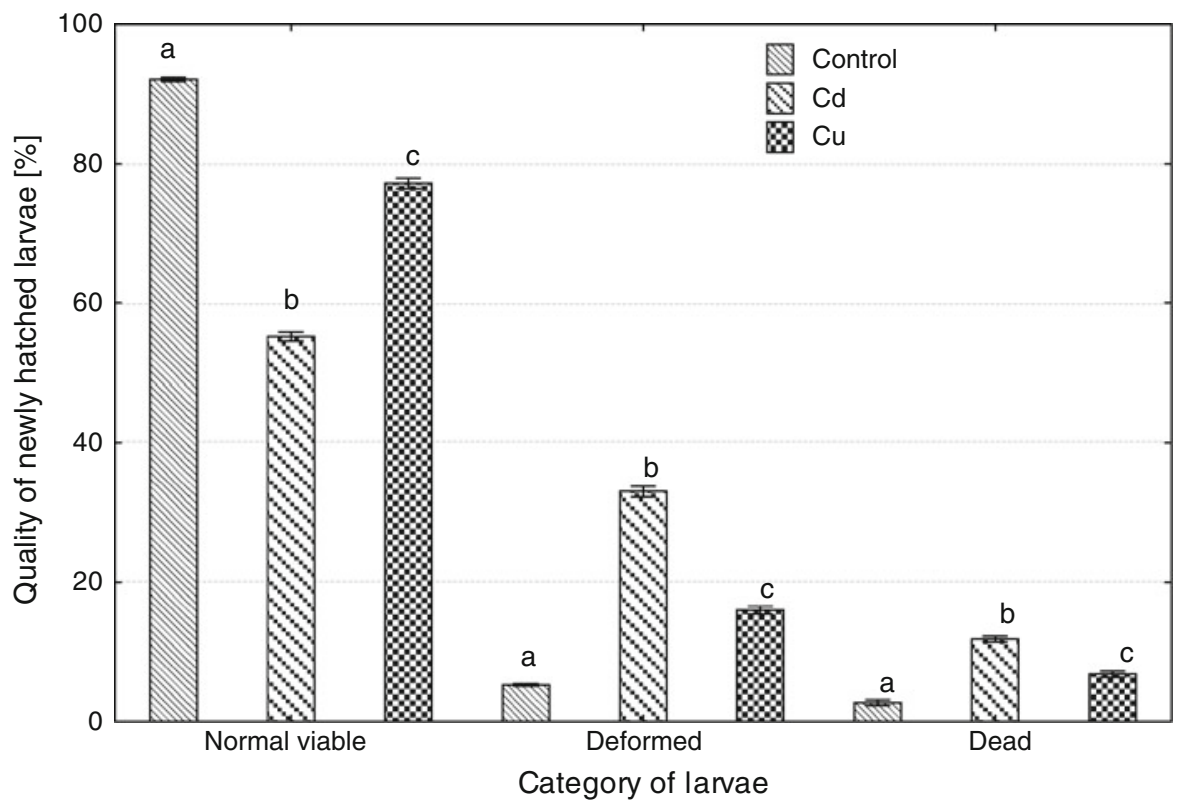

Fig. 2 The effects of embryonic exposure to $100 \mu \mathrm{g} / \mathrm{L}$ of cadmium or copper on the quality of newly hatched ide larvae (different letter superscripts indicate significant differences in

the ide from $\mathrm{Cd}-0$ and $0-\mathrm{Cd}$ groups were smaller compared to the control but significantly bigger than those from $\mathrm{Cd}-\mathrm{Od}$ (high individual variability occurred in these groups). The fish from $\mathrm{Cu}-\mathrm{Cu}$ and $0-\mathrm{Cu}$ groups were smaller than fish from the control but bigger than in $\mathrm{Cd}-\mathrm{Cd}$. The ratio of body perimeter area to the length was highest in the percentage of each category of larvae among experimental groups, $t$ test, $p \leq 0.05, n=4$ )

control (2.12 \pm 0.13$)$. Significantly, lower perimeter to length index was observed in all metal-exposed groups except for $\mathrm{Cd}-0$ (due to high individual variability in this group). The values of the index were: in $\mathrm{Cd}-\mathrm{Cd} 1.32 \pm 0.19$, in $\mathrm{Cu}-\mathrm{Cu} 1.82 \pm 0.16$, in $\mathrm{Cd}-01.86 \pm 0.61$, in $\mathrm{Cu}-02.04 \pm 0.10$, in $0-\mathrm{Cd}$ $1.87 \pm 0.25$ and in $0-\mathrm{Cu} 1.88 \pm 0.11$. 
Fig. 3 The effects of embryonic exposure to $100 \mu \mathrm{g} / \mathrm{L}$ of cadmium or copper on the size (body length and perimeter area) of newly hatched ide larvae (different letter superscripts indicate significant differences among experimental groups, $t$ test, $p \leq 0.05, n=30$ )

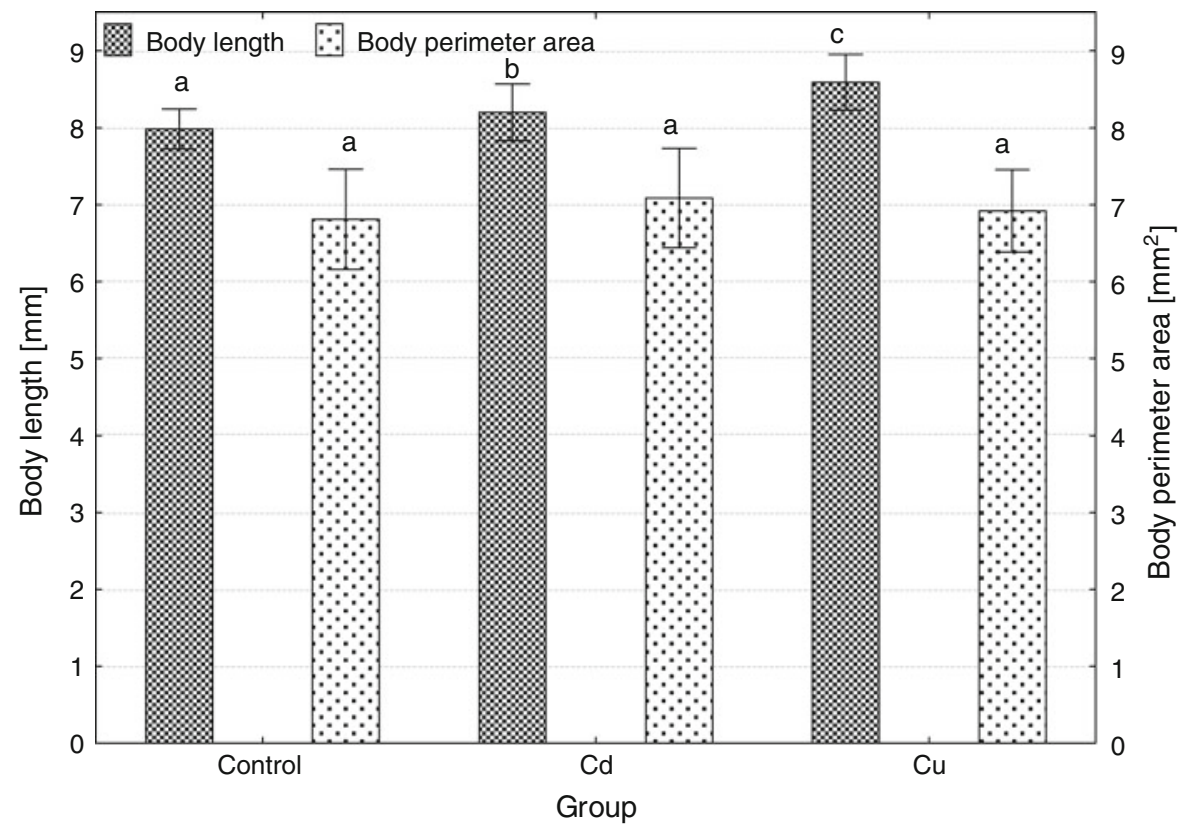

Fig. 4 The effects of embryonic exposure to $100 \mu \mathrm{g} / \mathrm{L}$ of cadmium or copper on the size (perimeter area) of the yolk sac in newly hatched ide larvae (different letter superscripts indicate significant differences among experimental groups, $t$ test, $p \leq 0.05, n=30$ )

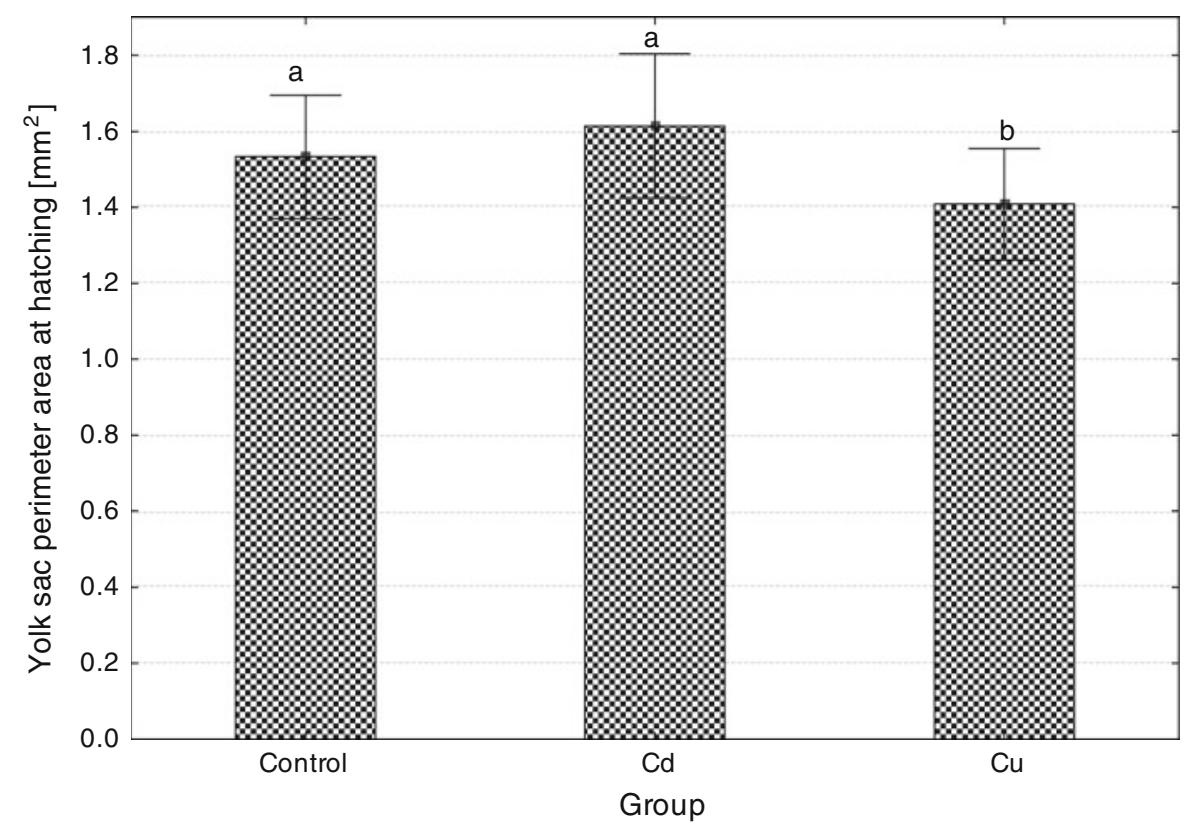

All ide larvae from the control and $\mathrm{Cu}-0$ groups completely utilized yolk on $7 \mathrm{dph}$, fish from $\mathrm{Cd}-0,0$ $\mathrm{Cd}$ and $0-\mathrm{Cu}$ on $9 \mathrm{dph}$, while those from $\mathrm{Cd}-\mathrm{Cd}$ and $\mathrm{Cu}-\mathrm{Cu}$ on $11 \mathrm{dph}$. First feeding was observed on the $5 \mathrm{dph}$ in the control, on the $7 \mathrm{dph}$ in $\mathrm{Cd}-0,0-\mathrm{Cd}, \mathrm{Cu}-0$ and $0-\mathrm{Cu}$, and on the $9 \mathrm{dph}$ in $\mathrm{Cd}-\mathrm{Cd}$ and $\mathrm{Cu}-\mathrm{Cu}$.

On the $3 \mathrm{dph}$, most fish from the control, $\mathrm{O}-\mathrm{Cu}, \mathrm{Cu}-$ 0 and $\mathrm{Cd}-\mathrm{Cd}$ started to inflate posterior chamber of the swim bladder, while in $\mathrm{Cu}-\mathrm{Cu}, \mathrm{Cd}-0$ and $0-\mathrm{Cd}$, the onset of swim bladder inflation took place on the $5 \mathrm{dph}$. Inflation of the anterior swim bladder chamber started later: on $13 \mathrm{dph}$ in the control and $\mathrm{Cu}-0$, on $15 \mathrm{dph}$ in $\mathrm{Cd}-0$, on $17 \mathrm{dph}$ in and $\mathrm{Cd}-\mathrm{Cd}$ and $\mathrm{Cu}-\mathrm{Cu}$ and on $19 \mathrm{dph}$ in $0-\mathrm{Cd}$ and $0-\mathrm{Cu}$. At the end of the experiment, fish from the control showed swim bladders significantly larger than in all metal-exposed 


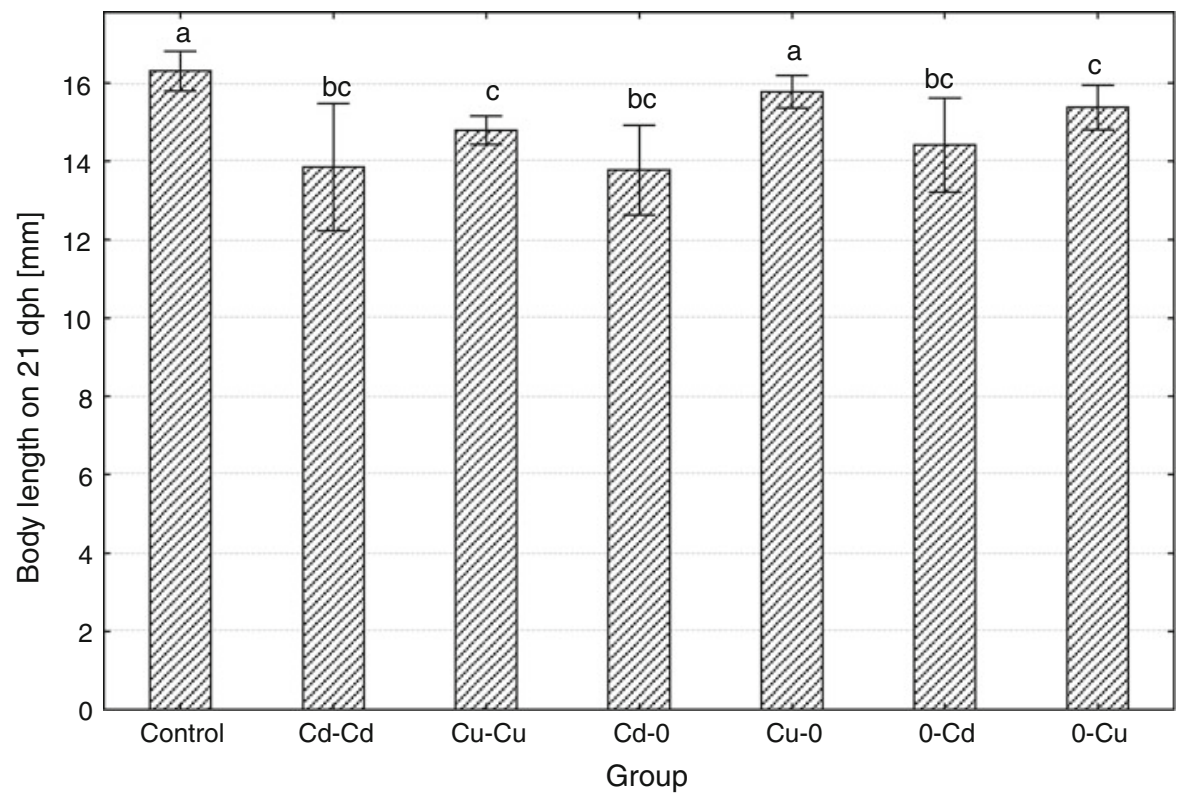

Fig. 5 The effects of exposure to $100 \mu \mathrm{g} / \mathrm{L}$ of cadmium or copper during embryonic or larval development or in both periods on body length of the ide larvae on the $21 \mathrm{dph}$ (different letter superscripts indicate significant differences among experimental groups, $t$ test, $p \leq 0.05, n=20$ )
Fig. 6 The effects of exposure to $100 \mu \mathrm{g} / \mathrm{L}$ of cadmium or copper during embryonic or larval development or in both periods on body perimeter area of the ide larvae on the $21 \mathrm{dph}$ (different letter superscripts indicate significant differences among experimental groups, $t$ test, $p \leq 0.05, n=20$ )

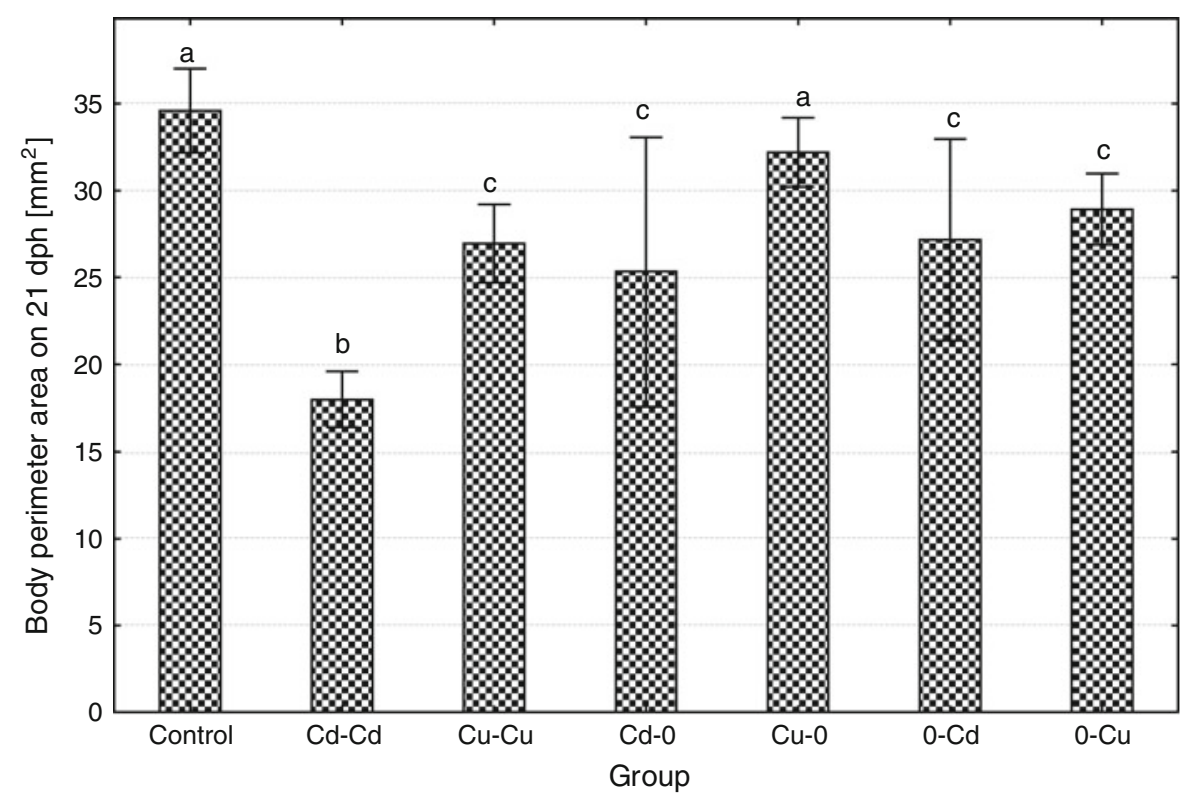

groups, while swim bladder perimeter area of the ide exposed continuously to cadmium $(\mathrm{Cd}-\mathrm{Cd})$ was the smallest (only about $30 \%$ of the size in the control) (Fig. 7). The size of posterior and anterior swim bladder chamber showed similar pattern (the results are not shown).

The most typical effects of $\mathrm{Cd}$ and $\mathrm{Cu}$ exposures on ide larvae are shown in Fig. 8. 


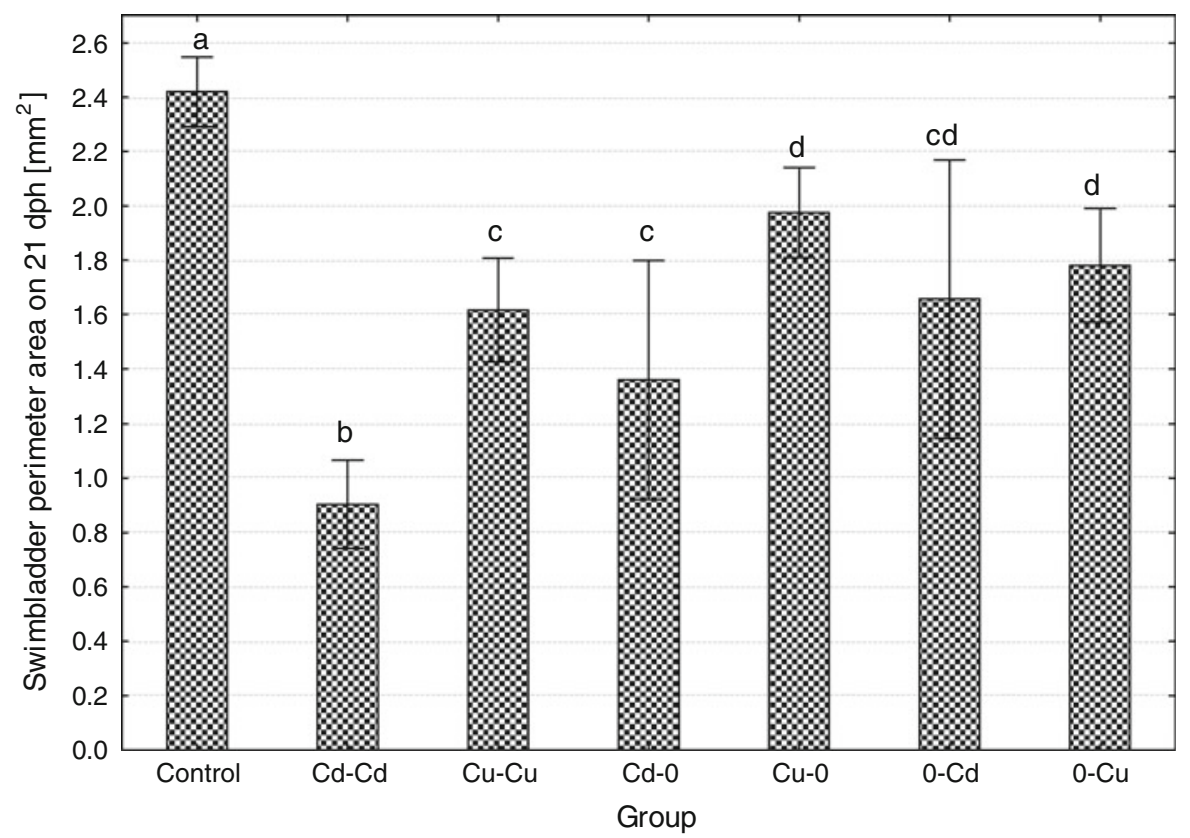

Fig. 7 The effects of exposure to $100 \mu \mathrm{g} / \mathrm{L}$ of cadmium or copper during embryonic or larval development or in both periods on the size (perimeter area) of swim bladder in the ide

\section{Discussion}

The obtained results show that copper and cadmium significantly reduced embryonic survival and quality of newly hatched larvae of the ide, cadmium being significantly more toxic compared to copper (Table 2). The results of many studies showed higher toxicity of copper compared to cadmium (literature review: Jezierska and Witeska 2001; Zhu et al. 2011). However, some data indicate that $\mathrm{Cd}$ is more toxic to early stages of some fish species than $\mathrm{Cu}$, e.g., Barjhoux et al. (2012) reported that LOEC of Cd and $\mathrm{Cu}$ for $O$. latipes embryos were 1.9 , and $8.5 \mu \mathrm{g} / \mathrm{L}$, respectively. Our results obtained for other cyprinid fishes showed that $\mathrm{Cu}$ was more toxic than $\mathrm{Cd}$ for $C$. carpio embryos and larvae (Jezierska et al. 2009a, b) but $\mathrm{Cd}$ was more toxic than $\mathrm{Cu}$ for B. barbus early life stages (Witeska et al. 2010; Ługowska and Kubik 2011). Similar effect was reported by Sikorska and Wolnicki (2010) for T. tinca larvae.

According to Alsop and Wood (2011), toxicity of cadmium and copper involves similar ionoregulatory disturbances. However, these authors observed different levels of reduction in calcium and sodium uptake and body level in D. rerio exposed to these metals: $\mathrm{Cd}$ larvae on the $21 \mathrm{dph}$ (different letter superscripts indicate significant differences among experimental groups, $t$ test, $p \leq 0.05, n=20$ )

reduced $\mathrm{Ca}$ uptake more than $\mathrm{Cu}$, while $\mathrm{Cu}$ reduced more Na uptake and whole body cation level than $\mathrm{Cd}$. According to Verbost et al. (1989), Cd reduces transepithelial $\mathrm{Ca}^{2+}$ influx due to inhibition of basolateral $\mathrm{Ca}^{2+}$ ATPase and blocking of apical $\mathrm{Ca}^{2+}$ channels. This may result in hypocalcemia (Pratap and Wendelaar Bonga 2007) and disturbances of calcium concentration gradient between extracellular and intracellular environment which is essential for various vital functions. Copper was reported to inhibit $\mathrm{Na}^{+} / \mathrm{K}^{+}$ATPase in fish (Li et al. 1998; Kulac et al. 2013). According to Pelgrom et al. (1995), copper causes a decrease in $\mathrm{Na}$ influx and $\mathrm{Na}$ plasma level in fish. According to McGeer et al. (2000), Cu or Cdexposed larvae of $O$. mykiss showed significantly reduced body $\mathrm{Na}^{+}$and $\mathrm{Ca}^{2+}$ concentrations. Therefore, the differences in sensitivity of various species of fish to toxicity of $\mathrm{Cd}$ and $\mathrm{Cu}$ are probably related to the intrinsic differences in sensitivity of their calcium and sodium homeostatic mechanisms. This issue, however, requires further detailed studies.

Both metals caused a delay of the beginning and the end of hatching of the ide larvae. Extended development duration of metal-exposed embryos resulted in hatching of significantly longer larvae, particularly in 

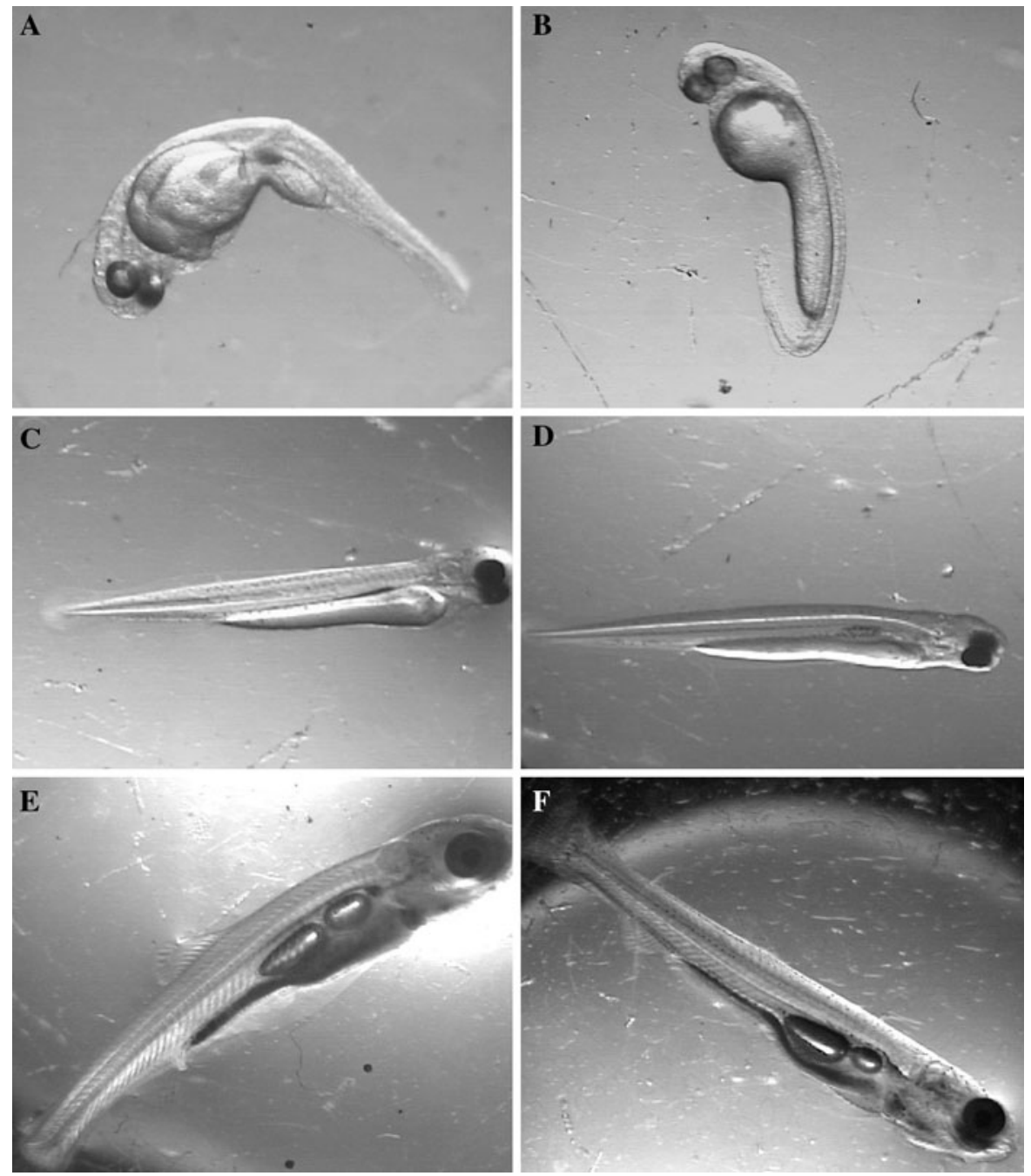

Fig. 8 Examples of the most typical effects of $\mathrm{Cd}$ and $\mathrm{Cu}$ exposures of ide larvae. a-d Newly hatched, e, f 21 days old. a Deformed from $\mathrm{Cd}, \mathbf{b}$ deformed from $\mathrm{Cu}$, $\mathbf{c}$ normal from the

$\mathrm{Cu}$-exposed group. These larvae were also significantly thinner compared to those from the control and Cd-exposed group, and showed the smallest yolk sac size at hatching. This indicates that $\mathrm{Cu}$-exposed embryos consumed the largest amount of nutrients compared to the control and $\mathrm{Cd}$ group. Significantly lower relative yolk size (proportion of the yolk to larval body size) suggests higher metabolic expenditure of $\mathrm{Cu}$-exposed embryos. Inhibition of Brachydanio rerio hatching by copper was reported by Dave and Xiu (1991). According to Lizardo-Daudt and Kennedy (2008), the effect of cadmium on hatching of O. mykiss depended on metal concentration: at 0.05

control (large yolk sac), d normal from $\mathrm{Cu}$ (small yolk sac), e from the control (large swim bladder), f from $\mathrm{Cd}$ - small swim bladder

and $0.25 \mu \mathrm{g} / \mathrm{L}$ premature hatching occurred, while at $2.5 \mu \mathrm{g} / \mathrm{L}$ hatching was delayed. Prolonged hatching time and increased mortality of newly hatched Pimephales promelas larvae in metal-contaminated lakes was reported by Gauthier et al. (2006). High rate of yolk utilization in $\mathrm{Cu}$-exposed fish might have been related to activation of metabolic mechanisms of metal sequestration, storage and excretion. According to Romeo et al. (2000), copper is more efficient in activating detoxification mechanisms of fish organism than cadmium. According to various authors, e.g., Roesijadi (1992) and Pelgrom et al. (1995), detoxification of heavy metals in fish involves binding to 
Table 2 Sensitivity of various embryonic and larval endpoints to cadmium and copper toxicity (as \% of change compared to the value in the control, statistically significant changes-bold, arrows indicate the direction of change)

\begin{tabular}{|c|c|c|c|c|c|c|}
\hline & \multicolumn{5}{|c|}{$\mathrm{Cd}$} & $\mathrm{Cu}$ \\
\hline \multicolumn{7}{|l|}{ Embryonic parameters } \\
\hline Survival at hatching & \multicolumn{5}{|c|}{$42.7 \downarrow$} & $30.8 \downarrow$ \\
\hline Frequency of deformed larvae & \multicolumn{5}{|c|}{$535 \uparrow$} & $208 \uparrow$ \\
\hline Frequency of dead larvae & \multicolumn{5}{|c|}{337} & $152 \uparrow$ \\
\hline Body length at hatching & \multicolumn{5}{|c|}{$2.8 \uparrow$} & $7.6 \uparrow$ \\
\hline Body perimeter area at hatching & \multicolumn{5}{|c|}{$4.1 \uparrow$} & $1.6 \uparrow$ \\
\hline \multirow[t]{2}{*}{ Yolk sac at hatching } & \multicolumn{4}{|c|}{$5.2 \uparrow$} & & $7.8 \downarrow$ \\
\hline & $\mathrm{Cd}-\mathrm{Cd}$ & $\mathrm{Cu}-\mathrm{Cu}$ & $\mathrm{Cd}-0$ & $\mathrm{Cu}-0$ & $0-\mathrm{Cd}$ & $0-\mathrm{Cu}$ \\
\hline \multicolumn{7}{|l|}{ Larval parameters } \\
\hline Survival on $21 \mathrm{dph}$ & $47.4 \downarrow$ & $13.7 \downarrow$ & $21.1 \downarrow$ & $7.4 \downarrow$ & $29.5 \downarrow$ & $23.2 \downarrow$ \\
\hline Body length on $21 \mathrm{dph}$ & $15.3 \downarrow$ & $9.2 \downarrow$ & $15.3 \downarrow$ & $3.1 \downarrow$ & $11.7 \downarrow$ & $5.5 \downarrow$ \\
\hline Body perimeter area on $21 \mathrm{dph}$ & $48.0 \downarrow$ & $22.0 \downarrow$ & $26.9 \downarrow$ & $6.9 \downarrow$ & $21.4 \downarrow$ & $16.5 \downarrow$ \\
\hline Swim bladder perimeter area on $21 \mathrm{dph}$ & $62.8 \downarrow$ & $33.1 \downarrow$ & $43.8 \downarrow$ & $18.2 \downarrow$ & $31.4 \downarrow$ & $26.4 \downarrow$ \\
\hline
\end{tabular}

metallothioneins that participate in homeostasis of essential elements (e.g., $\mathrm{Cu}$ ) and sequestration of xenobiotics (e.g., Cd).

Cadmium caused stronger increase in frequency of body malformation and higher mortality of newly hatched larvae than copper. Body deformities in $M$. fluviatilis larvae pulse-exposed to cadmium were reported by Williams and Holdway (2000). According to Mochida et al. (2009), vertebral deformities in Fundulus heteroclitus larvae exposed to copper pyrithione resulted from inhibition of acetylcholinesterase activity. Mechanism of body malformation in early developmental stages of fish due to metal toxicity is not clear. According to Muramoto (1981), cadmiuminduced body deformities in fish were related to a decrease in $\mathrm{Ca}$ and $\mathrm{P}$ content. Developmental abnormalities may also result from genotoxic action of $\mathrm{Cd}$ and $\mathrm{Cu}$ which was reported by various authors (e.g., Cavas et al. 2005; Rocha et al. 2010; Ozkan et al. 2011).

Similarly to the embryos, also, the larvae of ide were more affected by cadmium compared to copper: Survival, body length and perimeter area as well as swim bladder size were the most reduced in $\mathrm{Cd}-\mathrm{Cd}$ group compared to the control (Table 2). Decrease in fish growth caused by copper or cadmium intoxication may be a result of various metabolic disturbances. Couture and Kumar (2003) reported a direct inhibition of mitochondrial enzymatic activity and oxidative metabolism in Perca flavescens exposed to copper and cadmium. Metabolic costs of detoxification may also reduce growth of fish exposed to $\mathrm{Cd}$ and $\mathrm{Cu}$. According to $\mathrm{Wu}$ and Hwang (2003), $\mathrm{Cu}$ and $\mathrm{Cd}$ exposures induced metallothionein synthesis in $O$. mossambicus larvae. These metals also cause ionoregulatory disorders in fish which may cause increased metabolic cost of compensatory osmoregulation and growth reduction due to energetic deficiency. Slower growth of ide larvae exposed to cadmium and copper might have also resulted from delayed first feeding which occurred 2-4 days later than in the control (except for $\mathrm{Cu}-0$ group). It is noteworthy that only in $\mathrm{Cu}-0$ group body size of $21 \mathrm{dph}$ larvae did not significantly differ from the control. Delayed onset of exogenous feeding in $B$. barbus larvae exposed to $100 \mu \mathrm{g} / \mathrm{L}$ of cadmium or copper was observed by Witeska et al. (2010). The data obtained by Hernandez et al. (2006), Linbo et al. (2006) and Johnson et al. (2007) showed that copper induces lateral line dysfunction in fish larvae. On the other hand, cadmium impaired olfactory sense in D. rerio larvae (Kusch et al. 2007). Therefore, growth reduction in $\mathrm{Cd}$ - and $\mathrm{Cu}$-exposed fish may result from impaired perception and reduced food uptake.

Almost all groups of larvae exposed to cadmium and copper showed later yolk resorption and the onset of active feeding compared to the control, and the effect was the most pronounced in fish subjected to 
metal intoxication during embryonic and larval periods. The time of beginning of swim bladder inflation was less affected; however, final size of this organ was considerably reduced in almost all metal-exposed groups. Various authors also observed a delay of yolk absorption in fish larvae intoxicated with heavy metals. According Hwang et al. (1995) observed that O. mossambicus larvae exposed to $200 \mu \mathrm{g} / \mathrm{L}$ of copper had larger yolk sacs and were shorter compared to the control. According to $\mathrm{Wu}$ et al. (2003a, b) $O$. mossambicus larvae exposed to $30-400 \mu \mathrm{g} / \mathrm{L}$ of copper also showed reduced yolk utilization rate. Johnson et al. (2007) reported that the rate of yolk utilization by the larvae of $D$. rerio intoxicated with $\mathrm{Cu}$ at the concentration of 50-1,090 $\mu \mathrm{g} / \mathrm{L}$ was reduced in a concentration-related way. Sarnowski (2003) observed delayed yolk sac resorption by $C$. carpio larvae exposed to $200 \mu \mathrm{g} / \mathrm{L}$ of copper or cadmium. According to Sikorska and Wolnicki (2010), larvae of T. tinca exposed for $24 \mathrm{~h}$ to $100-300 \mu \mathrm{g} / \mathrm{L}$ of $\mathrm{Cd}$ or $\mathrm{Cu}$ showed reduced growth, survival and retarded swim bladder inflation. The same authors (Sikorska and Wolnicki 2006) reported similar effects accompanied by a delayed onset of exogenous feeding in Scardinius erythrophthalamus larvae exposed to Cd. According to Stouthart et al. (1996), a delay of yolk utilization in fish larvae intoxicated with heavy metals may result from reduced metabolic rate or from a direct adverse effect of metals on yolk material.

The results show that exposures to copper and cadmium during embryonic period alone caused adverse impact on larval performance, even when larval development took place in clean water. However, survival, growth and development of fish exposed to $\mathrm{Cu}$ only during embryonic period $(\mathrm{Cu}-0)$ were less affected than in case of embryonic $\mathrm{Cd}$ exposure (Cd-0). Also, exposure of embryos to $\mathrm{Cu}$ reduced toxic impact of metal on larvae: Mortality on $21 \mathrm{dph}$ in $\mathrm{Cu}-\mathrm{Ou}$ group was lower compared to $0-\mathrm{Cu}$, but no such an effect was observed for $\mathrm{Cd}$. This indicates the possibility of acclimation to $\mathrm{Cu}$ toxicity by preexposure. Little is known about acclimation mechanisms in early developmental stages of fish. Possibility of acclimation of post-swimup larvae of Salmo trutta by exposure of embryos or preswimup larvae to cadmium was observed by Brinkman and Hansen (2007). According to Sellin et al. (2005), acclimation of Pimephales promelas larvae to $\mathrm{Cu}$ required only 4 days of preexposure, while in juveniles, it took 16 days which indicates high acclimation potential at early stages. Wu and Hwang (2003) found that $\mathrm{Cd}$ and $\mathrm{Cu}$ stimulated metallothionein synthesis in $O$. mossambicus larvae. Induction of metallothionein synthesis in larvae may also result from maternal $\mathrm{Cd}$ exposure (Wu et al. 2012).

The results show that cadmium was more toxic to the ide embryos and larvae than copper, and even a short-term exposure to $\mathrm{Cd}$ or $\mathrm{Cu}$ during early development of ide may adversely affect recruitment of this species. Taking into consideration continuous exposure of ide embryos and larvae to Cd sensitivity of measured endpoints was quality of newly hatched larvae $>$ swim bladder size $>$ survival of $21 \mathrm{dph}$ larvae $>$ survival at hatching $>$ larval body size at $21 \mathrm{dph}$. In case of continuous $\mathrm{Cu}$ exposure, the ranking was quality of newly hatched larvae $>$ swim bladder size $>$ survival at hatching $>$ larval body size at $21 \mathrm{dph}>$ survival of $21 \mathrm{dph}$ larvae.

Open Access This article is distributed under the terms of the Creative Commons Attribution License which permits any use, distribution, and reproduction in any medium, provided the original author(s) and the source are credited.

\section{References}

Adamiec E, Helios-Rybicka E (2002) Distribution of pollutants in the Odra River system. Part V. Assessment of total and mobile heavy metals content in suspended matter and sediments of the Odra River system and recommendations for river chemical monitoring. Pol J Environ Stud 11: $675-688$

Allner B, Wegener G, Knacker T, Stahlschmidt-Allner P (1999) Electrophoretic determination of estrogen-induced protein in fish exposed to synthetic and naturally occurring chemicals. Sci Total Environ 233:21-31

Alsop D, Wood CM (2011) Metal uptake and acute toxicity in zebrafish: common mechanisms across multiple metals. Aquat Toxicol 105:385-393

Barjhoux I, Baudrimont M, Morin B, Landi L, Gonzalez P, Cachot J (2012) Effects of copper and cadmium spikedsediments on embryonic development of Japanese medaka (Oryzias latipes). Ecotoxicol Environ Saf 79:272-282

Braunbeck T, Segner H (1992) Preexposure temperature acclimation and diet as modifying factors for the tolerance of golden ide (Leuciscus idus melanotus) to short-term exposure to 4-chloroaniline. Exotoxicol Environ Saf 24: 72-94

Brinkman SN, Hansen DL (2007) Toxicity of cadmium to early life stages of brown trout (Salmo trutta) at multiple water hardnesses. Environ Toxicol Chem 26:1666-1671

Cao L, Huang W, Liu J, Yin X, Dou S (2010) Accumulation and oxidative stress biomarkers in Japanese flounder larvae and 
juveniles under chronic cadmium exposure. Comp Biochem Physiol C 151:386-392

Cavas T, Garanko NN, Arkhipchuk VV (2005) Induction of micronuclei and binuclei in blood, gill and liver cells of fishes subchronically exposed to cadmium chloride and copper sulphate. Food Chem Toxicol 43:569-574

Chen MF, Apperson JA, Marty GD, Cheng YW (2006) Copper sulfate treatment decreases hatchery mortality of larval white seabass Atractoscion nobilis. Aquaculture 254:102-114

Chen W-Y, Lin C-J, Ju Y-R, Tsai J-W, Liao C-M (2012) Coupled dynamics of energy budget and population growth of tilapia in response to pulsed waterborne copper. Ecotoxicology 21:2264-2275

Cieśla M, Wojda R (2004) Effect of domestication on ide Leuciscus idus L. reproductive parameters. J Fish Biol 65:316

Couture P, Kumar PR (2003) Impairment of metabolic capacities in copper and cadmium contaminated wild yellow perch (Perca flavescens). Aquat Toxicol 64:107-210

Dave G, Xiu R (1991) Toxicity of mercury, copper, nickel, lead and cobalt to embryos and larvae of zebrafish, Brachydanio rerio. Arch Environ Contam Toxicol 21:126-134

Dojlido JR (1995) Chemistry of surface waters. Ekonomia i Środowisko (in Polish)

Fenske C, Daeschlein G, Gunther B, Knauer A, Rudolph P, Schwahn C, Adrian V, von Woedtke T, Rossberg H, Julich W-D, Kramer A (2006) Comparison of different biological methods for the assessment of ecotoxicological risks. Int $\mathbf{J}$ Hyg Environ Health 209:275-284

Fraysse B, Mons R, Garric J (2006) Development of a zebrafish 4-day embryo-larval bioassay to assess toxicity of chemicals. Ecotoxicol Environ Saf 63:253-267

Gauthier C, Couture P, Pyle GG (2006) Metal effects on fathead minnows (Pimephales promelas) under field and laboratory conditions. Ecotoxicol Environ Saf 63:253-364

Hamackova J, Lepicova A, Prokes M, Lepic P, Kozak P, Policar T, Stanny AL (2007) Success of nursing ide (Leuciscus $i d u s$, L.) fry related to the period of feeding with live food. Aquacult Int 15:255-265

Hernandez PP, Allende ML (2008) Zebrafish (Danio rerio) as a model for studying the genetic basis of copper toxicity, deficiency, and metabolism. Am J Clin Nutr 88(suppl): 8358-8395

Hernandez PP, Moreno V, Olivari FA, Allende ML (2006) Sublethal concentrations of waterborne copper are toxic to lateral line neuromasts in zebrafish (Danio rerio). Hear Res 213:1-10

Hwang PP, Lin SW, Lin HC (1995) Different sensitivities to cadmium in tilapia larvae (Oreochromis mossambicus; Teleostei). Arch Environ Contam Toxicol 29:1-7

Ismail A, Yusof S (2011) Effect of mercury and cadmium on early life stages of Java medaka (Oryzias javanicus): a potential tropical test. Mar Pollut Bull 63:347-349

Jezierska B, Słomińska I (1997) The effect of copper on common carp (Cyprinus carpio L.) during embryonic and postembryonic development. Pol Arch Hydrobiol 44:261-272

Jezierska B, Witeska M (2001) Metal toxicity to fish. Wydawnictwo Akademii Podlaskiej, Siedlce, Poland, 318 pp

Jezierska B, Ługowska K, Witeska M (2009a) The effects of heavy metals on embryonic development of fish (a review). Fish Physiol Biochem 35:625-640
Jezierska B, Sarnowski P, Witeska M, Ługowska K (2009b) Disturbances of early development of fish caused by heavy metals (a review). Electron J Ichthyol 5(2):76-96

Johnson A, Carew E, Sloman KA (2007) The effects of copper on the morphological and functional development of zebrafish embryos. Aquat Toxicol 84:431-438

Krejszeff S, Targońska K, Żarski D, Kucharczyk D (2009) Domestication affects spawning of the ide (Leuciscus idus) — preliminary study. Aquaculture 295:145-147

Kulac B, Atli G, Canli M (2013) Response of ATPases in the osmoregulatory tissues of freshwater fish Oreochromis niloticus exposed to copper in increased salinity. Fish Physiol Biochem 39:391-401

Kusch RC, Krone PH, Chivers DP (2007) Chronic exposure to low concentrations of waterborne cadmium during embryonic and larval development results in the long-term hindrance of antipredator behavior in zebrafish. Environ Toxicol Chem 27:705-710

Lenyen M, Duvivier L, Girboux P, Ollevier F (1998) Toxicity of ozone to fish larvae and Daphnia magna. Ecotoxicol Environ Saf 41:176-179

Li J, Quabius ES, Wendelaar Bonga SE, Flik G, Lock RAC (1998) Effects of water-borne copper on branchial chloride cells and $\mathrm{Na}^{+} / \mathrm{K}^{+}$-ATPase activities in Mozambique tilapia (Oreochromis mossambicus). Aquat Toxicol 43:1-11

Linbo TL, Stehr CM, Incardona JP, Scholz NL (2006) Dissolved copper triggers cell death in the peripheral mechanosensory system of larval fish. Ecotoxicol Environ Chem 25:597-603

Linbo TL, Baldwin DH, McIntyre JK, Scholz NL (2009) Effects of water hardness, alkalinity, and dissolved organic carbon on the toxicity of copper to the lateral line of developing fish. Environ Toxicol Chem 28:1455-1461

Liu C-T, Chou M-Y, Lin C-H, Wu SM (2012) Effects of ambient cadmium with calcium on mRNA expressions of calcium uptake related transporters in zebrafish (Danio rerio) larvae. Fish Physiol Biochem 38:966-977

Lizardo-Daudt HM, Kennedy C (2008) Effects of cadmium chloride on the development of rainbow trout Oncorhynchus mykiss early life stages. J Fish Biol 73:702-718

Ługowska K, Kubik J (2011) Malformations of barbel (Barbus barbus) larvae induced by copper and cadmium. Ochrona Środowiska i Zasobów Naturalnych 48:171-179

McGeer JC, Szebedinszky C, McDonald DG, Wood CM (2000) Effects of chronic sublethal exposure to waterborne $\mathrm{Cu}, \mathrm{Cd}$ or $\mathrm{Zn}$ in rainbow trout: ionoregulatory disturbance and metabolic costs. Aquat Toxicol 50:231-243

Mochida K, Ito K, Harino H, Tanaka H, Onduka T, Kakuno A, Fujii K (2009) Inhibition of acetylcholinesterase by metabolites of copper pyrithione (CuPT) and its possible involvement in vertebral deformity of a CuPT-exposed marine teleostean fish. Comp Biochem Physiol C 149:624-630

Muramoto S (1981) Vertebral column damage and decrease of calcium concentration in fish exposed experimentally to cadmium. Environ Pollut Ser A Ecol Biol 24:125-133

Nguyen LTH, Janssen CR (2002) Embryo-larval toxicity tests with the African catfish (Clarias gariepinus): comparative sensitivity of endpoints. Arch Environ Contam Toxicol 42:256-262

Ozkan F, Gunduz SG, Berkoz M, Ozluer Hunt A (2011) Induction of micronuclei and other nuclear abnormalities 
in peripheral erythrocytes of Nile tilapia, Oreochromis niloticus, following exposure to sublethal cadmium doses. Turk J Zool 35:585-592

Paquin PR, Zoltay V, Winfield RP, Wu KB, Mathew R, Santore RC, Di Toro DM (2002) Extension of the biotic ligand model of acute toxicity to a physiologically-based model of the survival time of rainbow trout (Oncorhynchus mykiss) exposed to silver. Comp Biochem Physiol 13 C:305-343

Pelgrom SMGJ, Lock RAC, Balm PHM, Wendelaar Bonga SE (1995) Integrated physiological response of tilapia, Oreochromis mossambicus, to sublethal copper exposure. Aquat Toxicol 32:303-320

Pratap HB, Wendelaar Bonga SE (2007) Calcium homeostasis in low and high calcium water acclimatized Oreochromis mossambicus exposed to ambient and dietary cadmium. J Environ Biol 28:385-393

Rocha CAM, Almeida VHC, Silva Pinheiro RHS, Cunha LA (2010) Micronuclei and other nuclear abnormalities in acara Aequidens tetramerus (Perciforms: Cichlidae) exposed to copper sulfate. UAKARI 6:57-66

Roesijadi G (1992) Metallothioneins in metal regulation and toxicity in aquatic animals. Aquat Toxicol 22:80-114

Romeo M, Bennani N, Gnassia-Barelli M, Lafaurie M, Girard JP (2000) Cadmium and copper display different responses towards oxidative stress in the kidney of the sea bass Dicentrarchus labrax. Aquat Toxicol 48:185-194

Sarnowski P (2003) The effects of metals on yolk sac resorption and growth of starved and fed common carp (Cyprinus carpio L.) larvae. Acta Sci Pol Piscaria 2:227-236

Sellin MK, Tate-Boldt E, Kolok AS (2005) Acclimation to Cu in fathead minnows: does age influence the response? Aquat Toxicol 74:97-109

Sikorska J, Wolnicki J (2006) Cadmium toxicity to rudd (Scardinius erythrophthalamus (L.)) larvae after shortterm exposure. Arch Pol Fish 14:15-27

Sikorska J, Wolnicki J (2010) Cadmium and copper toxicity to tench Tinca tinca (L.) larvae after a short-term exposure. Rev Fish Biol Fish 20:417-423

Słomińska I, Jezierska B (2000) The effect of heavy metals on postembryonic development of common carp Cyprinus carpio L. Arch Pol Fish 8:119-128

Stouthart XJHX, Haans JLM, Lock AC, Wendelaar Bonga SE (1996) Effects of water $\mathrm{pH}$ on copper toxicity to early life stages of the common carp (Cyprinus carpio). Environ Toxicol Chem 15:376-383

Straus DL, Mitchell AJ, Carter RR, Steeby JA (2012) Hatch rate of channel catfish Ictalurus punctatus (Rafinesque 1818) eggs treated with $100 \mathrm{mg} \mathrm{L}^{-1}$ copper sulphate pentahydrate. Aquacult Res 43:14-18

Verbost PM, Van Rood J, Flik G, Lock RAC, Wendelaar Bonga SE (1989) The movement of cadmium through freshwater trout branchial epithelium and its interference with calcium transport. J Exp Biol 145:185-197

Weis JS, Samson J, Zhou T, Skurnick J, Weis P (2003) Evaluating prey capture by larval mummichogs (Fundulus heteroclitus) as a potential biomarker for contaminants. Mar Environ Res 55:27-38

Williams ND, Holdway DA (2000) The effects of pulse-exposed cadmium and zinc on embryo hatchability, larval development, and survival of Australian crimson spotted rainbow fish (Melanotaenia fluviatilis). Environ Toxicol 15:165-173

Witeska M, Bilska K, Sarnowski P (2010) The effect of copper and cadmium on growth and yolk utilization in barbel (Barbus barbus L.) larvae. Pol J Environ Stud 19:227-230

Wolnicki J, Górny W (1995) Controlled rearing of ide (Leuciscus idus L.) larvae using live food and dry feed. Aquaculture 129:255-256

Wu S-M, Hwang P-P (2003) Copper or cadmium pretreatment increases the protection against cadmium toxicity in tilapia larvae (Oreochromis mossambicus). Zool Stud 42:179-185

Wu SM, Jong KJ, Kuo YS (2003a) Effects of copper sulfate on ion balance and growth in tilapia larvae (Oreochromis mossambicus). Arch Environ Contam Toxicol 45:357-363

Wu SM, Jong KJ, Kuo SY (2003) Effects of copper sulfate on ion balance and growth of tilapia larvae (Oreochromis mossambicus). Arch Environ Contam Toxicol 45:357-363. www.fishbase.org

Wu SM, Tsai PR, Yan CJ (2012) Maternal cadmium exposure induces $\mathrm{mt} 2$ and smtB mRNA expression in zebrafish (Danio rerio) females and their offspring. Comp Biochem Physiol C 156:1-6

Zhang H, Cao H, Meng Y, Jin G, Zhu M (2012) The toxicity of cadmium $\left(\mathrm{Cd}^{2+}\right)$ towards embryos and pro-larva of Soldatov's catfish (Silurus soldatovi). Ecotoxicol Environ Saf 80:258-265

Zhu B, Wu Z-F, Li J, Wang G-X (2011) Single and joint action toxicity of heavy metals on early developmental stages of Chinese rare minnow (Gobiocypris rarus). Ecotoxicol Ennviron Saf 74:2193-2202

Zyśk B (2013) The distribution of cadmium and copper in fish organs. J Microbiol Biotechnol Food Sci 2:2306-2309 